\title{
OPERATIONS RESEARCH SUPPORT TO FORCE AND OPERATIONS PLANNING IN THE NEW SECURITY ENVIRONMENT
}

\author{
NATO Science for Peace Project SFP-981149 - developing \\ capabilities for Decision Support to the Security Sector
}

I $\mathrm{n}$ the beginning of the $21^{\text {st }}$ Century NATO members and partner countries face a major challenge - to transform their military and security organizations to deal effectively with terrorist threats, proliferation of WMD, organized crime, cyber attacks on critical services and infrastructure, etc. Countries need to organize, equip and train security forces that would smoothly interact-among themselves, as well as with forces from other nations and with non-governmental organizations - in order to prevent and react to a broad spectrum of threats and challenges.

To this purpose, the project aims to provide timely and effective scientific support, drawing on existing and developing novel operations research methods and models, in order to meet current and anticipated needs of end users from defense establishments, interior ministries, and civil protection agencies both in change management and support of computer aided exercises. In addition, project results will be incorporated in the curricula of Bulgaria's Defense and Staff College and the Academy of the Ministry of the Interior.

In this three-year research effort Bulgaria will establish a Center of Excellence in Operations Research (OR), attracting promising young scientists, conducting cuttingedge research on force and security-sector transformation and network-enabled operations, and facilitating the integration within the NATO's OR community.

This project networks the supplementary capabilities of several academic and research organizations from Bulgaria (the C4I Research and Development Department of the Institute for Parallel Processing and the Operations Research Department of the Institute of Mathematics and Informatics, both at the Bulgarian Academy of Sciences, and the Defense and Force Management Department of the Rakovski Defense and Staff College), from Germany (Niemeyer Operations Analyses) and The Netherlands 
(the Operations Research and Business Management Division at TNO Defense, Security and Safety). Associate Professor Dr. Velizar Shalamanov, Sofia, Bulgaria, and Mr. Klaus Niemeyer, Ottobrunn, Germany, are the Principal Project Co-Directors.

Additional information is available at the project website:

www.bas.bg/clpp/c4i_page/sfp/index.html 